\section{What rights for animals?}

The claim that animals have rights is not so much false as nonsensical and irrelevant.

ROBERT Nozick, the Harvard University philosopher, wrote last week in the New York Times that animal rights is a subject that seems to attract cranks. The distinguishing feature of a crank, he was quick to point out, is not merely preoccupation with a single issue; the solving of the world's problems, after all, may well require a division of labour. What really defines a crank, Nozick said, is that he has no sense of proportion. If some of the correspondence provoked by a recent leading article on animal rights (Nature 13 October, p.562) is any guide, Nozick might have added to that definition a lack of a sense of humour. The more thoughtful correspondents (10 November, p.110; 27 October p.758), however, have raised some serious points that deserve a more serious answer. Is it permissible for humans to violate an animal's "right"' to life only in those cases where strong moral arguments can be summoned to defend the action? How can animals be denied rights that severely retarded humans enjoy? What moral principles guide us in resolving the inevitably conflicting interests of humans and lower animals?

These are the questions that preoccupy philosophers and legitimate animal rightists. They are also totally unnecessary if one rejects from the outset - for the absurdity that it is - the notion that animals have "rights". Sarcasm perhaps failed to make that point; perhaps some commonsense arguments can. Simply, an animal is not a human being, nor an infant human being, nor a mentally retarded human being. An animal does not share human values, cannot grow up to be a being that shares human values, nor is a handicapped version of such a being. We need not even consider whether a healthy ape is a more free and feeling agent than a severely retarded human to recognize the uniquely corrupting effect on human values that comes of abridging the latter's rights. The real reason to defend the rights of severely handicapped humans is not that life is sacred in the abstract or that a being's ability to feel confers upon it an automatic right to exist; rather, it is the moral danger of allowing humans to pass arbitrary judgement on the rights of other humans. With good reason, we fear that society is unable to draw clear lines; crudely, once we admit the principle that select groups of humans can have their rights curtailed, it will not be long before someone will begin selecting on the basis of race, religion or political persuasion.

The same argument simply does not apply to animals. Even the most ardent advocate of animal rights acknowledges, explicitly or otherwise, a hierarchy of species. The ardent animal rightist does not bemoan the millions of bacteria he kills when he takes a bath. The argument is not that rights for cows means bacteria must be allowed to vote; we all recognize the need to draw lines and we should all recognize the fallacy of the argument that it is impossible to draw a line in a continuum (an acorn is not a tree even if it does by imperceptible degrees become one). The real objection to the animal rightists' view is that since we all recognize a hierarchy of species, why is it somehow morally compelling to draw the line between bacteria and insects, say, but morally reprehensible to draw a line between humans and all others?

In honesty, we should acknowledge, too, that as humans we are a part of the natural world, a world that is in a constant state of tension and competing interests between species. We should resist the temptation of viewing the natural world as a blissful, magical kingdom, save only for man, a clod with heavy boots trampling the flowers. The "sentient, purposeful" creatures of the wild lead difficult, violent, parasitized and short lives. Man's exploitation of animals for his own survival is hardly a perverse departure from the natural order. And, in the context of putting man's actions in perspective, those who oppose his exploitation of animals for research should ponder the 13.5 million dogs and cats that are put down in the United States each year for no reason whatsoever except that no one will take them as pets. (In Britain, ten times as many are killed in this way as in laboratory experiments - see page 527.)

None of this implies that human beings can treat animals as they choose. Perversion - and corruption of human values of compassion - undeniably comes from pointless cruelty to animals. That we recognize a moral obligation to treat animals with compassion and to respect their undeniable interests is evident in laws prohibiting cruelty and requiring the preservation of species from extinction. But there are simply no consistent or universal principles that imbue animals with "rights" as exercised by humans. Individuals may of course differ in their personal tastes, and there is nothing wrong with one's personal compassion outweighing any desire to eat meat, for example. But we should all eschew the self-righteous delusion that our tastes are universal moral truths.

\section{Science for the young}

\section{British primary schools have made the teaching of science sensible. Now they must make it exciting.}

How would you find out whether a ball that bounces best on one surface bounces best on all surfaces? How would you tell why a snail will not cross a ring of salty water? These are some of the questions that have been put to 11-year-olds in British primary schools by a group of investigators from Chelsea College, London, and the University of Leeds, as part of a survey of the science skills of British children sponsored by the Assessment of Performance Unit of the Department of Education and Science. The outcome, surprisingly, is encouraging. In these and other questions like them, roughly half of a representative sample of children (girls as well as boys) provided a reasonably convincing account of how they would set about the tasks assigned. Surrounding a snail alternatively with distilled water and brine, for example, was widely recommended as a way of understanding its behaviour. That about half of 11-year-olds grasped the essence of the problem is, in all charity, as much a triumph for British schools as the fact that half failed to get the point is a proof of failure. That few also pointed out that an attempt should be made, when repeating the experiment, to control for other variables is hardly a cause for shame, at 11 .

That is the bright side of the coin. It suggests that in the past decade, a substantial number of teachers in British primary schools have abandoned the once-popular belief that the innocence of childhood observation coupled with tender unbridled imagination together constitute an approach to the understanding of the natural world distinct from science but just as valid. It seems that the days have gone when primary school teachers believed that if a child were encouraged to exercise his natural gifts for long enough, he would be discovered to have rediscovered Newton's laws or, better still, some alternative to them. The most encouraging aspect of the survey is the evident concern of teachers that young children should be able to tackle simple problems constructively, and by methods that will yield results. That children appear less able to provide general statements explaining disparate observations is not nearly as shocking as the report suggests. A frustration of childhood, only partly compensated for by imaginativeness, is that useful hypotheses derive more from knowledge than observation.

So why should young children bother with science? The most obvious defect of the investigations so far is that they say little about motivation except that, at least at eleven, girls are just as interested as boys. But everyday experience with young children suggests a zeal and obsessiveness with natural phenomena of a kind much admired in able graduate students, and which is not well catered for in primary schools. Separating salt from sand is still one of the standard experiments hardly likely to do much to satisfy (and thus stimulate) curiosity about the way in which the Universe is put together. No doubt the authors of the survey would point out that science in British primary schools has come a long way and is now going in the right direction. But there is a long way to go, even in the fortunate absence (in British schools) of controversies about such issues as creationism. 